\title{
TCDD Alters Pituitary-Adrenal Function II: Evidence for Decreased Bioactivity of ACTH
}

\author{
LORELLE L. BESTERVELT, ${ }^{*} \dagger$, JEFF A. PITT, ${ }^{*} \dagger$ \\ COLLEEN J. NOLAN*† AND WALTER N. PIPER* ${ }^{*} \S^{1}$ \\ *Toxicology Program, School of Public Health, †Reproductive Sciences Program, and \\ \$Department of Pharmacology, Medical School, The University of Michigan, Ann Arbor, MI 48109-2029
}

Received 6 April 1993; Accepted 18 June 1993

\begin{abstract}
BESTERVELT, L. L., J. A. PITT, C. J. NOLAN AND W. N. PIPER. TCDD alters pituitary-adrenal function II: Evidence for decreased bioactivity of ACTH. NEUROTOXICOL TERATOL 15(6) 371-376, 1993. - The present study assessed the ability of primary cultures of rat anterior pituitary cells to secrete bioactive ACTH in the presence of $2,3,7$, 8-tetrachlorodibenzo-p-dioxin (TCDD). The bioactivity of the secreted pituitary cell ACTH was determined by its ability to stimulate secretion of corticosterone from primary cultures of rat adrenal cells. ACTH from basal or CRH stimulated pituitary cells treated with TCDD was found to be less capable of stimulating corticosterone secretion from primary rat adrenal cell cultures than equimolar concentrations of ACTH purchased from a commercial supplier. Corticosterone secretion from adrenal cell cultures treated with ACTH from basal or CRH stimulated pituitary cell cultures exposed to TCDD was decreased by 60 and $70 \%$, respectively. The decreased ability to stimulate corticosterone secretion can be overcome when extracts of ACTH from pituitary cell cultures treated with TCDD are supplemented with commercial ACTH. These findings indicate that TCDD may alter the bioactivity of secreted ACTH from the anterior pituitary gland.
\end{abstract}
$2,3,7,8$-Tetrachlorodibenzo-p-dioxin
Adrenocorticotropin (ACTH)
Corticotropin releasing hormone (CRH)

\begin{abstract}
Corticosterone Pituitary gland Adrenal gland
\end{abstract}
IN the preceding paper we demonstrated that $2,3,7,8$ tetrachlorodibenzo-p-dioxin (TCDD; $50 \mu \mathrm{g} / \mathrm{kg}$; single, oral dose) causes an early (day 1) and persistent (day 14) increase in rat plasma ACTH concentrations. However, plasma corticosterone concentrations in the rat were not consistantly increased or were actually decreased in spite of the increased plasma ACTH concentrations during this 14-day period. It has also been reported that TCDD-treatment decreases plasma corticosterone concentrations in the rat as early as day 4 after exposure (16). Under normal regulation, increased plasma ACTH concentrations should result in consistently elevated plasma corticosterone concentrations which was not observed, suggesting that TCDD may be able to decrease the capacity of the adrenal gland to respond to ACTH. In the preceding paper we also assessed the capacity of adrenal glands from rats treated with TCDD (50 $\mu \mathrm{g} / \mathrm{kg}$; single, oral dose) to respond to ACTH stimulation. It was discovered that adrenal responsiveness to exogenous ACTH was not changed by exposure to TCDD. Another possible mechanism for decreased plasma corticosterone concentrations in response to elevated plasma ACTH concentrations may be that TCDD directly effects the anterior pituitary to modify the synthesis and/or secretion of a less potent/bioactive form of ACTH. Secretion of a less bioactive form of ACTH may explain the lack of a consistent increase in plasma corticosterone in response to elevated plasma ACTH in TCDD-treated rats. Because ACTH is the primary regulator of adrenal steroidogenesis, a shift from a more bioactive form to a less bioactive form would be expected to interfere with adrenal steroidogenesis. Therefore, it would be important to study the effects of TCDD on the bioactivity of ACTH. This study was designed to test the effects of TCDD on the ability of primary cultures of rat anterior pituitary cells to synthesize and secrete bioactive ACTH. The bioactivity of the secreted pituitary cell ACTH was assessed by its ability to stimulate secretion of corticosterone from primary cultures of rat adrenal cells.

\section{METHOD}

\section{Primary Cultures of Anterior Pituitary Cells}

After decapitation, pituitary glands were aseptically removed from 20-25 untreated Sprague-Dawley male rats (180$220 \mathrm{~g}$ ) obtained from The Reproductive Sciences Program of The University of Michigan. Posterior pituitary tissue was separated from the anterior pituitary and discarded. Anterior pituitary tissue was quartered and enzymatically dispersed in

\footnotetext{
${ }^{1}$ Requests for reprints should be addressed to Dr. Walter N. Piper, Director Toxicology Program, The University of Michican, M6108, SPH-II, 1420 Washington Heights, Ann Arbor, MI 48109-2029.
} 
$20 \mathrm{ml}$ Dulbecco's Modified Eagle's Medium (DMEM) (Gibco BRL; Grand Island, NY) using $0.35 \%$ type I collagenase (Sigma, St. Louis, MO) in a shaking water bath $\left(37^{\circ} \mathrm{C}\right)$ for $60 \mathrm{~min}(21)$. The tissue fragments were allowed to settle for approximately $2 \mathrm{~min}$ and the media containing the collagenase was aspirated from the tissue fragments using a sterile flametipped Pasteur pipette. Complete DMEM (CDMEM: $2.2 \mathrm{~g} / 1$ sodium bicarbonate, $2.5 \%$ bovine calf serum, $10 \%$ horse serum, $100 \mathrm{IU} / \mathrm{ml}$ penicillin, $100 \mathrm{mg} / \mathrm{ml}$ streptomycin, $0.1 \%$ bovine serum albumin, and $10 \mathrm{mM}$ HEPES at $\mathrm{pH}$ 7.4) was added $(5 \mathrm{ml})$ to the tissue fragments $(15 \mathrm{ml})$. The resulting mixture was passed through a sterile flame-tipped Pasteur pipette to facilitate dissociation of the anterior pituitary cells from the pituitary gland's support membranes. The membranous debris was allowed to settle for approximately $2 \mathrm{~min}$ before media samples were removed, pooled, and placed into a sterile $50 \mathrm{ml}$ conical tube. This process was repeated three times to recover a maximal number of anterior pituitary cells. The resulting pooled cell suspension was brought to a final volume of $45 \mathrm{ml}$ with CDMEM, and centrifuged at $500 \times g$ for $20 \mathrm{~min}$ at $5^{\circ} \mathrm{C}$ to pellet the cells. The pellet was gently resuspended in $5 \mathrm{ml}$ of CDMEM using a sterile flame-tipped Pasteur pipette. The cell suspension was brought to $20 \mathrm{ml}$ with CDMEM and centrifuged as previously described. The cell concentration was determined using a hemocytometer, diluted to $1 \times 10^{5}$ cells $/ \mathrm{ml}$, and plated in 24 well $16 \mathrm{~mm}$ culture plates at $1 \mathrm{ml} /$ well. The cells were maintained under standard culture conditions $\left(95 \%\right.$ air, $5 \% \mathrm{CO}_{2}, 37^{\circ} \mathrm{C}$ ) for the duration of the experiment. Before dosing, cells were allowed to attach for 4 days. TCDD was dissolved in dimethyl sulfoxide (DMSO) at a concentration of $10 \mathrm{mM}$ just before addition to culture medium. Control samples were exposed to equal volumes of DMSO. Cell viability after TCDD treatment was assessed by trypan blue exclusion.

\section{Primary Cultures of Adrenal Cells}

After decapitation, adrenal glands were aseptically removed from 20-25 untreated Sprague-Dawley male rats (180$220 \mathrm{~g})$ that were obtained from The Reproductive Sciences Program of The University of Michigan. Adrenal glands were trimmed of adhering fat and quartered. The quartered glands were enzymatically dispersed in $20 \mathrm{ml}$ Dulbecco's Modified Eagle's Medium/Ham's F-12(DMEM/F-12) (Gibco BRL; Grand Island, NY) containing $0.25 \%$ type I collagenase (Sigma; St. Louis, MO) in a shaking water bath for $\mathbf{3 0}$ min at $37^{\circ} \mathrm{C}(10,19,21)$. The cell suspension was allowed to settle for approximately $2 \mathrm{~min}$ before $20 \mathrm{ml}$ of medium were removed and placed into a sterile $50 \mathrm{ml}$ conical tube. Complete DMEM/F-12 (CDMEM/F-12: $2.2 \mathrm{~g} / 1$ sodium bicarbonate, $2.5 \%$ bovine calf serum, $10 \%$ horse serum, $100 \mathrm{IU} / \mathrm{ml}$ penicillin, $100 \mathrm{mg} / \mathrm{ml}$ streptomycin, $0.1 \%$ bovine serum albumin, and $10 \mathrm{mM}$ HEPES at $\mathrm{pH} 7.4)$ was added $(5 \mathrm{ml})$ to approximately $10 \mathrm{ml}$ of the original cell suspension. The resulting mixture was passed through a sterile flame-tipped Pasteur pipette to facilitate dissociation of the adrenal cells from the adrenal gland's support membranes. The membranous debris was allowed to settle for approximately $2 \mathrm{~min}$ before media samples were removed, pooled, and placed into a sterile $50 \mathrm{ml}$ conical tube. This process was repeated three times to recover a maximal number of adrenal cells. The resulting pooled suspension was brought to a final volume of $45 \mathrm{ml}$ with CDMEM/F-12, and centrifuged at $500 \times g$ for $20 \mathrm{~min}$ at $5^{\circ} \mathrm{C}$ to pellet the cells. The pellet was gently resuspended in CDMEM/F-12 and centrifuged as previously described. The cell concentration was determined using a hemocytometer, diluted to $5 \times 10^{5}$ cells $/ \mathrm{ml}$, and plated in $35 \mathrm{~mm}$ petri dishes. Treatments were applied in serum-free media to prevent effects of sera from confounding the effects of TCDD. The ability of cells to exclude trypan blue was utilized following treatments in dishes to assess the effects of TCDD on cell viability.

\section{ACTH Bioactivity Experiments}

Primary cultures of rat anterior pituitary cells were initiated as described above. Cells were treated with TCDD $(0$, $10^{-9}, 10^{-11}$, or $10^{-13} \mathrm{M}$ ) for 3 days. At the end of the treatment period, basal media samples from four petri dishes (1 $\mathrm{ml}$ from each petri dish) were pooled (total pooled media collected was $4 \mathrm{ml}$, and $200 \mu \mathrm{l}$ was removed for ACTH measurement). For the CRH (Peninsula; Belmont, CA) stimulated study, cells were treated with TCDD $\left(0,10^{-9}, 10^{-11}\right.$, or $10^{-13}$ M) for 3 days. After the treatment period, cells were rinsed with media $(1 \mathrm{ml})$ and then stimulated with $10^{-7} \mathrm{M} \mathrm{CRH}$ for $5 \mathrm{~h}$. This concentration of $\mathrm{CRH}$ has been shown to stimulate the synthesis and secretion of ACTH by cultured anterior pituitary cells $(18,20,21)$. Following $\mathrm{CRH}$ stimulation, media samples from four petri dishes $(1 \mathrm{ml}$ from each petri dish) were pooled (total pooled media collected was $4 \mathrm{ml}$, and $200 \mu \mathrm{l}$ was removed for ACTH measurement).

After primary cultures of rat adrenal cells had reached confluency ( 7 days), they were rinsed with DMEM/F-12 (1 $\mathrm{ml}$ ) and were challenged with basal pituitary media or CRH stimulated pituitary media (from controls and TCDD-treated pituitary cells) containing ACTH equivalent to $10^{-10} \mathrm{M}$ by RIA for $5 \mathrm{~h}$ to determine the effect of TCDD on the bioactivity of secreted pituitary ACTH. Adrenal cells were also stimulated with $\mathrm{ACTH}\left(10^{-10} \mathrm{M} ; 1-39\right.$ human $\left.\mathrm{ACTH}\right)$ purchased from Sigma Chemical Co., St. Louis, MO (exogenous ACTH) and compared with corticosterone secretion from basal and CRH stimulated pituitary ACTH media from TCDD-treated pituitary cells. Following stimulation, media samples were collected and stored at $-20^{\circ} \mathrm{C}$ until measurement of corticosterone.

Several controls were used to ensure that media or hormonal treatments did not alter corticosterone secretion. The controls consisted of: a) equal volumes of adrenal medium (DMEM/F-12); b) equal volumes of pituitary medium, (DMEM); c) $10^{-10} \mathrm{M}$ commercially purchased ACTH (the concentration of ACTH in pooled samples from TCDDtreated basal or TCDD-treated CRH stimulated pituitary media after RIA determination), and d) $10^{-10} \mathrm{M} \mathrm{ACTH}+10^{-7}$ M CRH.

Adrenal cell cultures were also treated with pooled basal pituitary media from the $0,10^{-9}, 10^{-11}$, or $10^{-13} \mathrm{M}$ TCDDtreated groups supplemented with $10^{-10} \mathrm{M}$ ACTH purchased from Sigma Chemical Co., St. Louis, MO (exogenous ACTH) and stimulated for $5 \mathrm{~h}$ to ensure that TCDD did not interfere with ACTH stimulation of corticosterone secretion by adrenal cell cultures. Adrenal cell cultures were also stimulated with ACTH $\left(10^{-10} \mathrm{M}\right)$ purchased from Sigma Chemical Co., St. Louis, MO (exogenous ACTH), which served as a positive control. Following stimulation, media samples were collected and stored at $-20^{\circ} \mathrm{C}$ until measurement of corticosterone. Cell viability was $\mathbf{9 0 \%}$ or greater for all treatments tested.

\section{ACTH and Corticosterone Measurements}

ACTH was measured using a commercially available RIA kit (Diagnostic Products Corporation, Los Angeles, CA). The 


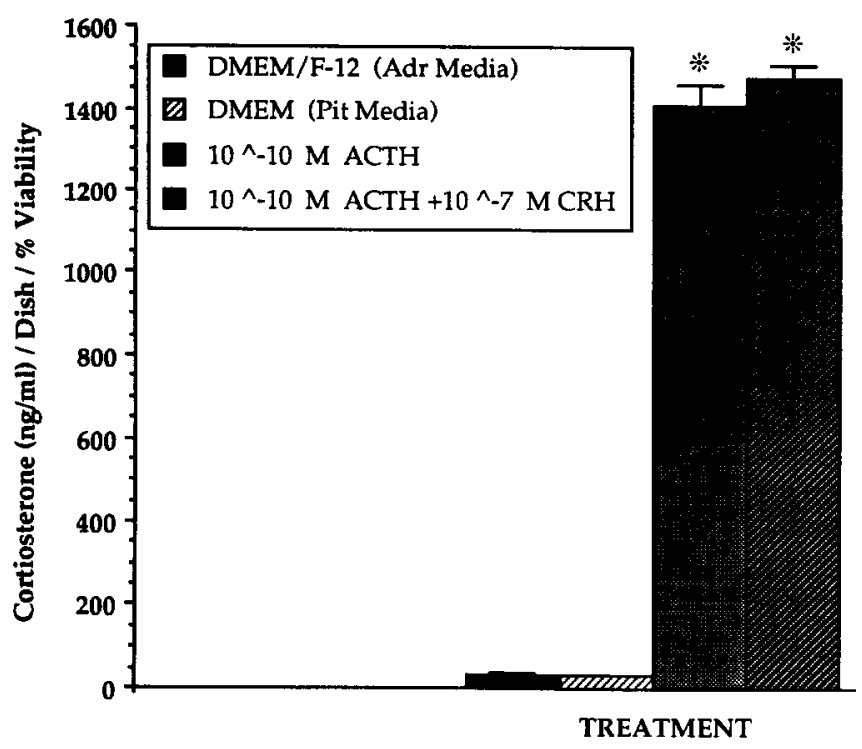

FIG. 1. Adrenal cell cultures were treated with DMEM/F-12 (adrenal control media), DMEM (pituitary media), $10^{-10} \mathrm{M}$ ACTH or $10^{-10} \mathrm{M} \mathrm{ACTH}+10^{-7} \mathrm{M}$ CRH for $5 \mathrm{~h}$ to determine their effects on corticosterone secretion. Following stimulation, adrenal media samples were collected and corticosterone was measured by RIA. Values represent the mean \pm SEM for seven dishes. An asterisk denotes that the difference between media and hormonal treatments was statistically significant $(p<0.05)$.

ACTH antibody recognizes amino acids 1-24 from the $\mathrm{N}$ terminus and crossreactivites ranged from $0.35 \%$ for $\alpha-\mathrm{MSH}$ to nondetectible for Met- and Leu-enkephalin and $\beta$-endorphin. Intra- and interassay coefficients of variation for ACTH were $6 \%$ and $9 \%$, respectively. Sensitivity of the ACTH RIA was $8 \mathrm{pg} / \mathrm{ml}$. Corticosterone was also measured using a commercially available RIA kit (ICN Biochemicals Inc., Costa Mesa, CA). Sensitivity of the corticosterone RIA was $10 \mathrm{ng} /$ $\mathrm{ml}$ and the intra- and interassay coefficients of variation were $7 \%$ and $8 \%$, respectively. All assays were conducted as described by the manufacturer's protocol.

\section{Statistical Analysis}

Data were analyzed using one-way analysis of variance or Student's $t$-test to compare differences between means $(p<$ 0.05).

\section{RESULTS}

Corticosterone secretion by primary rat adrenal cell cultures exposed to media, ACTH, or CRH is shown in Fig. 1. Basal corticosterone secretion is represented by DMEM/F-12 (adrenal medium) and served as a positive control. Pituitary medium (DMEM) did not change corticosterone secretion. Corticosterone concentrations were significantly increased in adrenal cell cultures that were treated with $10^{-10} \mathrm{M} \mathrm{ACTH}$ (exogenous ACTH) demonstrating that the adrenal cells respond to their appropriate hormonal stimulus. Because stimulated pituitary media samples contained both $\mathrm{CRH}$ and ACTH, it was important to determine corticosterone secretion by adrenal cells exposed to both of these hormones. Pituitary media samples containing $10^{-10} \mathrm{M} \mathrm{ACTH}$ and $10^{-7} \mathrm{M} \mathrm{CRH}$ did not differ in their ability to stimulate corticosterone secre- tion from adrenal cell cultures treated with $10^{-10} \mathrm{M}$ ACTH (Fig. 1), demonstrating that CRH had no effect on corticosterone secretion. Cell viability was $\mathbf{9 0 \%}$ or greater for all treatments tested.

Corticosterone secretion by adrenal cells after treatment with pooled basal media samples from pituitary cultures treated with TCDD is shown in Fig. 2. In this experiment, basal media samples were pooled from TCDD-treated pituitary cells and ACTH concentrations were determined for each concentration of TCDD $\left(10^{-9}-10^{-13} \mathrm{M}\right)$. The average concentration of ACTH for each of the pooled fractions was $10^{-10} \mathrm{M}$ ACTH (five determinations for each pooled sample). Control basal media samples contained less than $10^{-14} \mathrm{M}$ ACTH. Commercially purchased ACTH $\left(10^{-10} \mathrm{M}\right.$, exogenous ACTH) was used as the concentration to stimulate corticosterone secretion by adrenal cell cultures to serve as a positive control. Pooled pituitary media samples from all TCDD treatment groups $\left(10^{-9} \mathrm{M}, 10^{-11} \mathrm{M}\right.$, and $\left.10^{-13} \mathrm{M}\right)$ stimulated secretion of $30-40 \%$ less corticosterone into the media by adrenal cell cultures than $10^{-10} \mathrm{M}$ exogenous ACTH. Controls comprising basal pituitary media did not change corticosterone secretion. Cell viability was $90 \%$ or greater for all treatments tested.

Corticosterone secretion by adrenal cells after treatment with pooled pituitary media samples from $\mathrm{CRH}$-stimulated TCDD-treatment groups is shown in Fig. 3. In this experiment, media samples were pooled from TCDD-treated pituitary cells that were stimulated with $\mathrm{CRH}$ and ACTH concentrations were determined for each concentration of TCDD $\left(10^{-9} \mathrm{M}, 10^{-11} \mathrm{M}\right.$, and $\left.10^{-13} \mathrm{M}\right)$. The average concentration

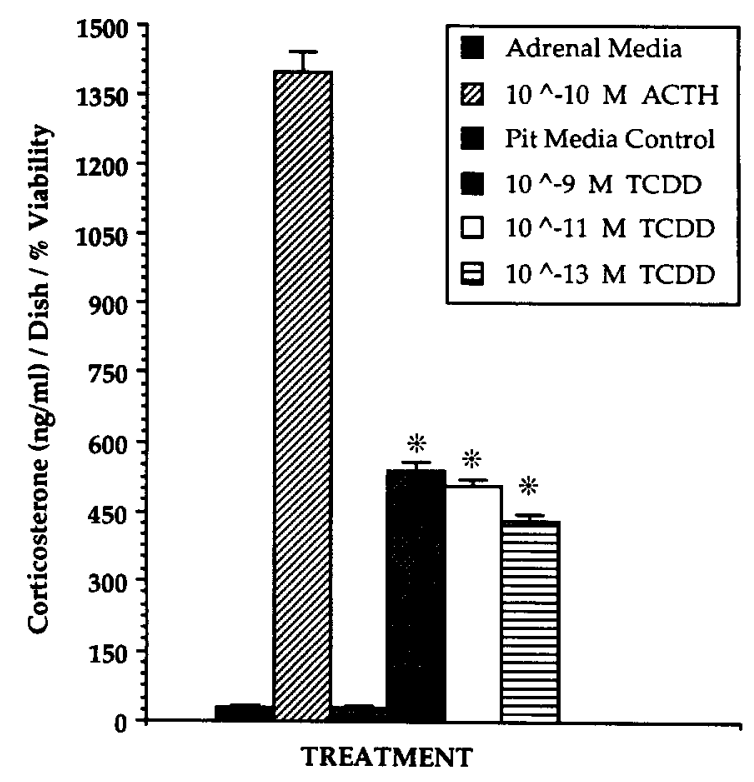

FIG. 2. Adrenal cell cultures were treated with pooled basal pituitary media samples from control $\left(<10^{-14} \mathrm{M}\right)$ or TCDD-treated pituitary cells (the ACTH concentration for the pooled media samples was $\left.10^{-10} \mathrm{M}\right)$ for $5 \mathrm{~h}$ to determine the effect of TCDD exposure on the bioactivity of secreted pituitary ACTH. Adrenal cells were also stimulated with commercially purchased $10^{-10} \mathrm{M}$ (exogenous) ACTH and compared to corticosterone secretion from pooled basal TCDDtreated pituitary media. Following stimulation, media samples were collected and corticosterone was measured by RIA. Values represent the mean \pm SEM for seven dishes. An asterisk denotes that the difference between pooled basal TCDD-treated pituitary media and control values was statistically significant $(p<0.05)$. 


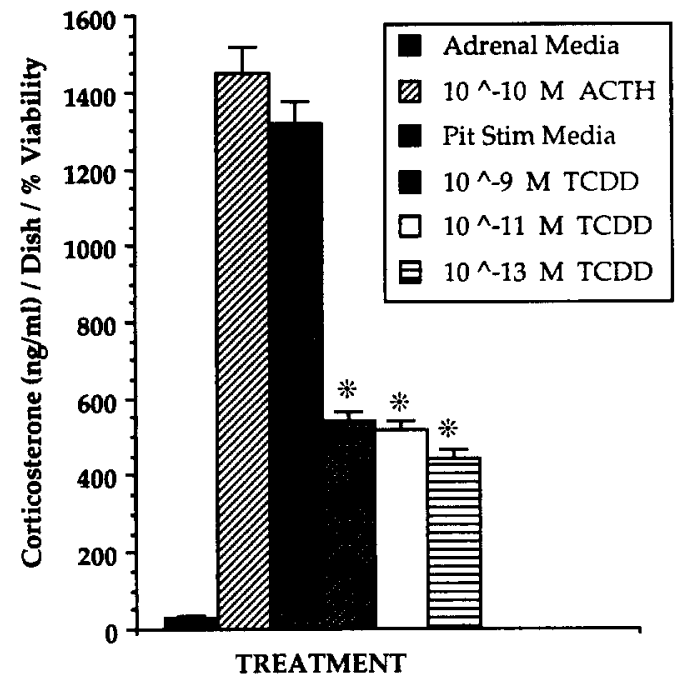

FIG. 3. Adrenal cell cultures were treated with pooled CRH stimulated pituitary media samples from control or treated pituitary cells (the ACTH concentration for the pooled media samples was $10^{-10} \mathrm{M}$ ) for $5 \mathrm{~h}$ to determine the effect of TCDD exposure on the bioactivity of secreted pituitary ACTH. Adrenal cells were also stimulated with commercially purchased $10^{-10} \mathrm{M}$ (exogenous) ACTH and compared to corticosterone secretion from pooled TCDD-treated CRH stimulated pituitary media. Following stimulation, media samples were collected and corticosterone was measured by RIA. Values represent the mean \pm SEM for seven dishes. An asterisk denotes that the difference between pooled CRH stimulated TCDD-treated pituitary media and control values was statistically significant $(p<0.05)$.

of ACTH for each of the pooled fractions was $10^{-10} \mathrm{M}$ ACTH (five determinations for each pooled sample). ACTH $\left(10^{-10}\right.$ $\mathrm{M}$, exogenous ACTH) was used as a positive control. Pooled pituitary media samples, stimulated with $\mathrm{CRH}$, from all TCDD-treatment groups $\left(10^{-9} \mathrm{M}, 10^{-11} \mathrm{M}\right.$, and $\left.10^{-13} \mathrm{M}\right)$, caused $55 \%-70 \%$ less corticosterone to be secreted into the media by adrenal cell cultures than $10^{-10} \mathrm{M}$ exogenous ACTH or controls consisting of pooled media samples from CRH stimulated pituitary media in the absence of TCDD. Note that pooled media samples from CRH stimulated pituitary cells stimulated corticosterone secretion by adrenal cell cultures as well as $10^{-10} \mathrm{M}$ exogenous ACTH. Cell viability was $90 \%$ or greater for all treatments tested.

These results indicate that pooled basal or CRH stimulated pituitary media samples from TCDD-treated pituitary cell cultures are less capable of stimulating corticosterone secretion from adrenal cell cultures than equimolar, exogenous ACTH. To confirm that the decreased bioactivity of ACTH was not caused by the presence of TCDD in the pooled pituitary media samples, TCDD $\left(10^{-9} \mathrm{M}, 10^{-11} \mathrm{M}\right.$, and $\left.10^{-13} \mathrm{M}\right)$-treated pituitary media supplemented with $10^{-10} \mathrm{M}$ exogenous ACTH was added to adrenal cell cultures and corticosterone secretion was assessed. The response of adrenal cell cultures to pituitary media samples supplemented with TCDD and $10^{-10} \mathrm{M}$ exogenous ACTH is shown in Fig. 4. Corticosterone secretion caused by pituitary media samples supplemented with TCDD and $10^{-10} \mathrm{M}$ exogenous ACTH did not differ from those supplemented with only $10^{-10} \mathrm{M}$ exogenous $\mathrm{ACTH}$, suggesting that TCDD contamination of pooled pituitary media samples was not responsible for the decreased bioactivity of ACTH in pituitary cell cultures that had been exposed to TCDD.
Furthermore, assay for TCDD in pooled media samples from pituitary cells treated with this toxicant by high resolution GC-low resolution MS (Dr. Matthew Zabic, Michigan State University; data not shown) yielded less than the level of detection of $3 \mathrm{ppt}\left(<10^{-14} \mathrm{M}\right)$, indicating that the presence of TCDD as a contaminant cannot explain the decreased bioactivity of ACTH.

\section{DISCUSSION}

The bioactivity of ACTH secreted from TCDD-treated basal or TCDD-treated CRH stimulated pituitary cell cultures was assessed in this study by testing the ability of each to stimulate secretion of corticosterone from primary rat adrenal cell cultures. We used the in vivo cell culture model to rule out the TCDD-induced weight loss as the cause of HPA perturbations observed in the previous paper (la). Pooled basal pituitary media samples from TCDD-treated cells, measured for their ACTH concentrations, were found to be less capable of stimulating secretion of corticosterone by adrenal cells than equimolar, exogenous ACTH. Also, pooled pituitary media samples from TCDD-treated cells treated with CRH, measured for their ACTH concentrations, were also found to be less capable of stimulating secretion of corticosterone by adrenal cells than equimolar, exogenous ACTH. It was expected that pooled media samples from basal or CRH stimulated TCDD-treated pituitary cells would stimulate corticosterone secretion in amounts equivalent to equimolar, exogenously supplied $10^{-10} \mathrm{M}$ ACTH. It :vas surprising to find that this did not happen. The inability to stimulate corticosterone secretion could be overcome when pituitary media samples from TCDD-treated cells were supplemented with additional exogenous ACTH. These findings support the hypothesis that TCDD may alter the bioactivity of ACTH secreted by the anterior pituitary gland and rule out TCDD-induced weight

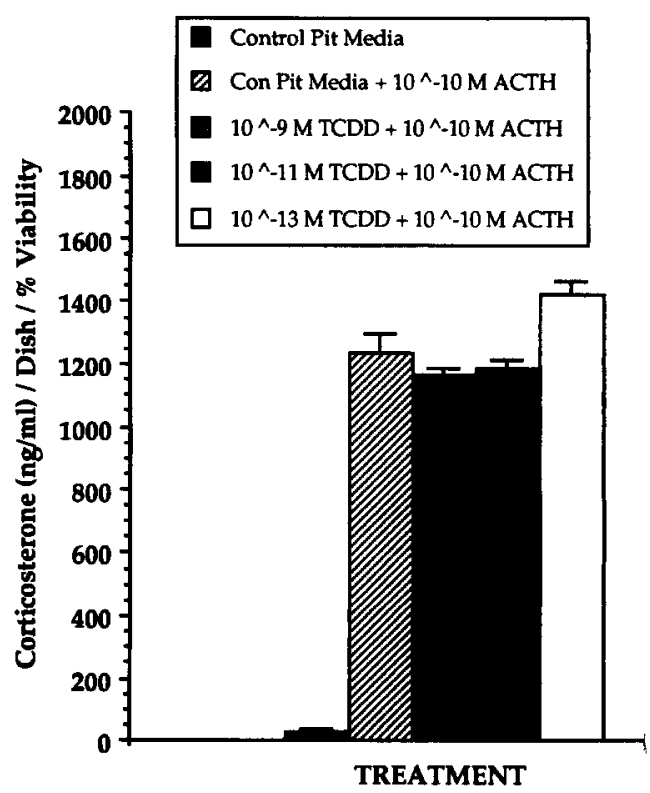

FIG. 4. Adrenal cell cultures were treated with pooled basal pituitary media supplemented with $10^{-10} \mathrm{M}$ ACTH from control or TCDDtreated pituitary cells for $5 \mathrm{~h}$. Following stimulation, media samples were collected and corticosterone was measured by RIA. Values represent the mean \pm SEM for seven dishes. 
loss as a cause of the observed HPA alterations. It is important to remember that pooled media samples from control CRH stimulated pituitary cells stimulated corticosterone secretion by adrenal cell cultures as well as $10^{-10} \mathrm{M}$ exogenous ACTH. The stimulation of corticosterone production by control pituitary secreted ACTH demonstrates that the harvesting procedure for pituitary cells did not cause an altered form of ACTH to be secreted.

ACTH is known to exist in several different processed and unprocessed forms with varying steroidogenic potencies. ACTH is synthesized from a large precursor molecule (31K pro-ACTH/endorphin). 31K Pro-ACTH/endorphin is posttranslationally processed to yield different peptides. The $31 \mathrm{~K}$ pro-ACTH/endorphin precursor is first proteolytically cleaved to a $22 \mathrm{~K}$ ACTH biosynthetic intermediate, which is further cleaved to yield a $16 \mathrm{~K}$ fragment and a $4.5 \mathrm{~K} \mathrm{ACTH}$ fragment $(1,4,8,9,20)$. Each fragment of $\mathrm{ACTH}$ has been shown to have different steroidogenic capacities. The $4.5 \mathrm{~K}$ ACTH is the most bioactive peptide of ACTH and has full steroidogenic potency as assessed by the synthesis and secretion of corticosterone by rat adrenal cell cultures $(3-6,13$, $17,22,24)$. In contrast, the steroidogenic potencies of the $31 \mathrm{~K}$ and $22 \mathrm{~K}$ peptides have been found to be 100 - and 300 -fold less than the $4.5 \mathrm{~K}$ fragment, respectively $(2,6,7,11,17)$. The $31 \mathrm{~K}$ and $22 \mathrm{~K}$ ACTH peptides are both found in normal pituitaries, ACTH-secreting pituitary tumors, ectopic ACTHsecreting tumors, and in plasma and are believed to have little inherent biological activity $(12,23,24)$. Therefore, it is possible that TCDD is able to preferentially influence the synthesis and secretion to the less processed forms of ACTH (31K and $22 \mathrm{~K}$ ) that have low adrenal steroidogenic potency.

Further support for this concept comes from studies conducted in rat anterior pituitary cells and mouse pituitary tumor cells. Secretion of these different ACTH peptide fragments varies under basal and $\mathrm{CRH}$ stimulated conditions $(5,8,14)$. Under basal conditions, the less processed forms (31K and 22K) are predominant; whereas, stimulation with ACTH secretagogues such as CRH potentiates the secretion of the bioactive forms of ACTH $(4.5 \mathrm{~K})(1,5,8,9,20)$. Furthermore, selective release of different ACTH peptide fragments has been demonstrated in rat anterior pituitary cell cultures (basal or CRH stimulated conditions) $(8,9)$. It is believed that peptides secreted under basal conditions originate from different intracellular pools than peptides secreted under the influence of ACTH secretagogues. These different pools respond to different secretory signals to produce and secrete different end products $(8,9)$. Thus, it is possible that during chronic TCDD treatment the newly synthesized peptides, which represent the unprocessed forms, are secreted in preference to the more processed forms that would be less available for secretion. Therefore, this mechanism could explain the observation that pooled pituitary media samples from TCDD-treated cells were less capable of stimulating secretion of corticosterone from adrenal cells than RIA-measurable, equimolar concentrations of exogenous ACTH.

Another possibility is that TCDD is able to alter POMC processing into the various bioactive peptide fragments. TCDD could inhibit an early step in the processing of the POMC molecule promoting the accumulation of larger precursor-sized forms of ACTH (31K and 22K). Chronic administration of the drug haloperidol is believed to alter POMC processing with accumulation of larger, precursor-sized forms of ACTH (15). It is possible that POMC processing could be retarded during TCDD treatment, resulting in the accumulation of larger precursor-sized forms of ACTH. This process could involve the depletion of proteolytic enzymes involved in the biosynthetic pathway, because these enzymes appear to be secreted together with the ACTH peptides during exocytosis from the secretory vesicles (14). TCDD exposure may also directly inhibit the proteolytic enzymes involved in the biosynthetic pathway, resulting in the accumulation of larger precursor-sized forms of ACTH (31K and 22K).

In summary, media samples from basal or CRH stimulated pituitary cells exposed to TCDD, measured for their ACTH content, are less capable of stimulating corticosterone secretion from adrenal cell cultures than equimolar, commercially purchased (exogenous) ACTH. The decreased ability to stimulate corticosterone secretion from adrenal cells can be overcome when pituitary media samples treated with TCDD are supplemented with additional exogenous ACTH. These results suggest that TCDD may be able to alter the bioactivity of ACTH, perhaps by shifting the form of ACTH that is being processed from the anterior pituitary gland. Because ACTH is the primary regulator of adrenal steroidogenesis, a shift from the more bioactive form of ACTH to a less bioactive form would be expected to impair adrenal steroidogenesis.

\section{ACKNOWLEDGEMENTS}

We thank Dr. Matthew Zabic (Michigan State University) for determining the concentration of TCDD in our pooled pituitary media samples, Dr. Huda Akil (The University of Michigan) for consultation and input regarding this study, and Dr. Paula A Bank (WarnerLambert, Parke-Davis) for helpful discussions and review of this manuscript.

This research was conducted as partial fulfillment of L.L.B.'s doctoral dissertation. This publication was made possible by grant number T 32 ES-07062 from the National Institute of Environmental Health Sciences, NIH and by grant number P 30 HD-18258.

\section{REFERENCES}

1. Allen, R. G.; Herbert, E.; Hinman, M.; Shibuya, H.; Pert, C. B. Coordinate control of ACTH, bLPH, and $\beta$-endorphin release in mouse pituitary cell cultures. Proc. Natl. Acad. Sci. USA 75: 4972-4976; 1978 .

1a. Bestervelt, L. L.; Cai, Y.; Piper, D. W.; Nolan, C. J.; Pitt, J. A.; Piper, W. N. TCDD alters pituitary-adrenal function I: Adrenal responsiveness to exogenous ACTH. Neurotox. Teratatol. 15: 365-370; 1993.

2. Coslovsky, R.; Schneider, B.; Yalow, R. S. Characterization of mouse ACTH in plasma and in extracts of pituitary and of adrenotropic pituitary tumor. Endocrinology 97:1308-1315; 1975.

3. Eipper, B. A.; Mains, R. E. High molecular weight forms of adrenocorticotropic hormone in the mouse pituitary and in a mouse pituitary cell line. Biochemistry 14:3836-3844; 1975.
4. Eipper, B. A.; Mains, R. E. Structure and biosynthesis of proadrenocorticotropin/endorphin and related peptides. Endocr. Rev. 1:1-27; 1980.

5. Eipper, B. A.; Mains, R. E. Existence of a common precursor to ACTH and endorphin in the anterior and intermediate lobes of the rat pituitary. J. Supramol. Struct. 8:247-262; 1978.

6. Gasson, J. C. Steroidogenic activity of high molecular weight forms of corticotropin Biochemistry 18:4215-4224; 1979.

7. Gewirtz, G.; Schneider, B.; Krieger, D. T.; Yalo , R. S. Big ACTH: Conversion to biologically active ACTH by trypsin. J. Clin. Endocrinol. Metab. 38:227-230; 1974.

8. Ham, J.; Smyth, D. G. $\beta$-Endorphin and ACTH related peptides in primary cultures of rat anterior pituitary cells: Evidence for different intracellular pools. FEBS 190:253-258; 1985. 
9. Ham, J.; Smyth, D. G. Chronic stimulation of anterior pituitary cell cultures with CRF leads to the secretion of lipotropin. Neuroendocrinology 44:433-438; 1986.

10. Hornsby, P. J.; O’Hare, M. J.; Neville, M. Functional and morphological observations on rat adrenal zona glomerulosa cells in monolayer culture. Endocrinology 95:1240-1253; 1974.

11. Krieger, D. T.; Choi, H. H.; Anderson, P. J. The characterization of the ACTH produced by a primary tumour in a patient with Cushing's disease. Clin. Endocrinol. 5:455-472; 1976.

12. Kreiger, D. T.; Liotta, A. S.; Brownstein, M. J.; immerman, E. A. ACTH, $\beta$-lipotropin, and related peptides in brain, pituitary, and blood. Rec. Prog. Horm. Res. 36:277-344; 1980.

13. Lang, R. E.; Fehm, H. L.; Voigt, K. H.; Pfeiffer, E. F. Two ACTH species in rat pituitary gland. FEBS Lett. 37:197-199; 1973.

14. Mains, R. E.; Eipper, B. A., Coordinate, equimolar secretion of smaller peptide products derived from pro-ACTH/endorphin by mouse pituitary tumor cells. J. Biol. Chem. 89:21-28; 1981.

15. Meador-Woodruff, J. H.; Pellerito, B.; Bronstein, D.; Lin, H.; Ling, N.; Akil, H. Differential effects of haloperidol on the rat pituitary: decreased biosynthesis, precessing and release of anterior lobe pro-opiomelanocortin. Neuroendocrinology 51:294$303 ; 1990$.

16. Mebus, C. A. 2, 3, 7, 8-Tetrachlorodibenzo-p-dioxin induced alterations of rats adrenal and testicular steroidogenesis. Thesis, University of Nebraska; 1987.

17. Orth, D. N.; Nicholson, W. E.; Mitchell, W. M.; Island, D. P.; Shapiro, M.; Byyny, R. L. ACTH and MSH production by a single cloned mouse pituitary tumor cell line. Endocrinology 92: 385-393; 1973.

18. Rivier, J.; Rivier, C.; Vale, W. Synthetic competitive antagonists of corticotropin-releasing factor: Effect of ACTH secretion in the rat. Science 224:889-891; 1984.

19. Simonian, M. H.; Gill, G. N. Regulation of deoxyribonucleic acid synthesis in bovine adrenocortical cells in culture. Endocrinology 104:588-595; 1979.

20. Vale, W.; Vaughan, J.; Smith, M.; Yamamoto, G.; Rivier, J.; Rivier, C. Effects of synthetic ovine corticotropin-releasing factor, glucocorticoids, catecholamines, neurophypophsial peptides, and other substances on cultured corticotropic cells. Endocrinology 113:1121-1131; 1983.

21. Vale, W. W.; Grant, G.; Amoss, M.; Blackwell, R.; Guillemin, R. Culture of enzymatically dispersed anterior pituitary cells: Functional validation of a method. Endocrinology 91:562-571; 1972.

22. Vale, W.; Rivier, C.; Yang, L.; Minick, S.; Guillemin, R. Effects of purified hypothalamic cortiocotropin-releasing factor and other substances on secretion of ACTH and $\beta$-endorphin-like immunoactivities in vitro. Endocrinology 103:1910-1915; 1978.

23. Yalow, R. S.; Berson, S. A. Size heterogeneity of immunoreactive human ACTH in plasma and in extracts of pituitary glands and ACTH-producing thymoma. Biochem. Biophys. Res. Commun. 44:439-445; 1971 .

24. Yalow, R. S.; Berson, S. A. Characteristics of "big ACTH" in human plasma and pituitary extracts. J. Clin. Endocrinol. Metab. $36: 415-423 ; 1973$. 